\title{
Assessing the carbon sink of afforestation with the Carbon Budget Model at the country level: an example for Italy
}

\author{
Roberto Pilli ${ }^{(1)}$, Giacomo Grassi ${ }^{(1)}$, Jose V Moris ${ }^{(2)}$, Werner A Kurz ${ }^{(3)}$
}

In the context of the Kyoto Protocol, the mandatory accounting of Afforestation and Reforestation (AR) activities requires estimating the forest carbon (C) stock changes for any direct human-induced expansion of forest since 1990. We used the Carbon Budget Model (CBM) to estimate $C$ stock changes and emissions from fires on AR lands at country level. Italy was chosen because it has one of the highest annual rates of AR in Europe and the same model was recently applied to Italy's forest management area. We considered the time period 1990-2020 with two case studies reflecting different average annual rates of AR: $78 \mathrm{kha} \mathrm{yr}^{-1}$, based on the 2013 Italian National Inventory Report (NIR, official estimates), and $28 \mathrm{kha} \mathrm{yr}^{-1}$, based on the Italian Land Use Inventory System (IUTI estimates). We compared these two different AR rates with eight regional forest inventories and three independent local studies. The average annual $C$ stock change estimated by CBM, excluding harvest or natural disturbances, was equal to $1738 \mathrm{Gg} \mathrm{C} \mathrm{yr}^{-1}$ (official estimates) and $630 \mathrm{Gg} \mathrm{C} \mathrm{yr}^{-1}$ (IUTI estimates). Results for the official estimates are consistent with the estimates reported by Italy to the KP for the period 2008-2010; for 2011 our estimates are about $20 \%$ higher than the country's data, probably due to different assumptions on the fire disturbances, the AR rate and the dead wood and litter pools. Furthermore, our analysis suggests that: (i) the impact on the AR sink of different assumptions of species composition is small; (ii) the amount of harvest provided by $A R$ has been negligible for the past $(<3 \%)$ and is expected to be small in the near future (up to $8 \%$ in 2020); (iii) forest fires up to 2011 had a small impact on the AR sink (on average, $<100 \mathrm{Gg} \mathrm{C} \mathrm{yr}^{-1}$ ). Finally the comparison of the historical AR rates reported by NIR and IUTI with other independent sources gives mixed results: the regional inventories support the AR rates reported by the NIR, while some local studies suggest AR rates somehow intermediate between NIR and IUTI. In conclusion, this study suggests that the CBM can be applied at country level to estimate the $C$ stock changes resulting from $A R$, including the effect of harvest and fires, though only a comparison with results based on direct field measurements could verify the model's capability to estimate the real $C$ stock change.

Keywords: Afforestation, Reforestation, Carbon Budget Model, Italy, INFC, IUTI

\section{Introduction}

In the context of the Land Use, Land-Use change and Forestry (LULUCF) sector of the Kyoto protocol (KP), Afforestation and Reforestation (AR) refers to the direct human- for less than 50 years (UNFCCC 2005). Since the same reporting and accounting rules apply to both activities, they are typically treated together (IPCC 2003, 2013).

For the first commitment period of the KP (2008-2012) the accounting of emissions and removals from AR is mandatory for Annex I (so-called developed) countries, i.e., all the carbon (C) stock changes in the five pools (above- and below-ground living biomass, dead wood, litter and soil) and the non- $\mathrm{CO}_{2}$ greenhouse gas (GHG) emissions contribute to the emissions reduction targets by countries. The recently agreed new LULUCF rules (UNFCCC 2011), confirmed the mandatory accounting of AR for the second commitment period of the KP (2013-2020) and introduced important changes (Grassi 2012), including the possibility to exclude from the accounting the emissions and removals related to natural disturbances on forest and AR lands, provided that the respective requirements are met.

Many studies have provided estimates on the $\mathrm{C}$ stock changes for Forest Management (FM, i.e., forest existing before 1 January 1990) or for the total forest area at both local (Mund et al. 2002, Masera et al. 2003), national (Karjalainen et al. 2002, Stinson et al. 2011, Pilli et al. 2013) and multi-national scale (Böttcher et al. 2012). For AR, while several studies analyzed $\mathrm{C}$ stock changes at the stand or local level (Thuille et al. 2000, Masera et al. 2003, Hoogmoed et al. 2012), extensive estimates based on direct field measures at the country level are lacking.

The contribution of AR removals to the GHG emission reduction targets may, however, be significant and - according to the country reports to the KP - it can be even more important than FM (Grassi et al. 2012). For instance, during 2008-2012 AR offset about $1 \%$ of total EU 1990 GHG emissions (EU 2013), and at least a similar contribution is expected for 2013-2020 (Grassi et al. 2012). For this reason, and given the increased reporting requirements set by the new LULUCF rules, a closer look at the emissions and removals from AR lands at the country level is useful from both a scientific and a political perspective.

The main objective of this study was to estimate the stock changes of the five forest $\mathrm{C}$ pools for the period 1990-2020, for AR lands and at country level. To this purpose we applied the Carbon Budget Model (CBM) developed by the Canadian Forest Service (Kurz et al. 2009) to AR lands of Italy. Two case studies for AR area were conducted, based on different literature data (Italy 2013, Corona et al. 2012, Marchetti et al. 2012). Italy was considered a good country case-study because it has one of the highest annual rates of AR in the EU and because the same CBM was recently applied to

Communicated by: Marco Borghetti 


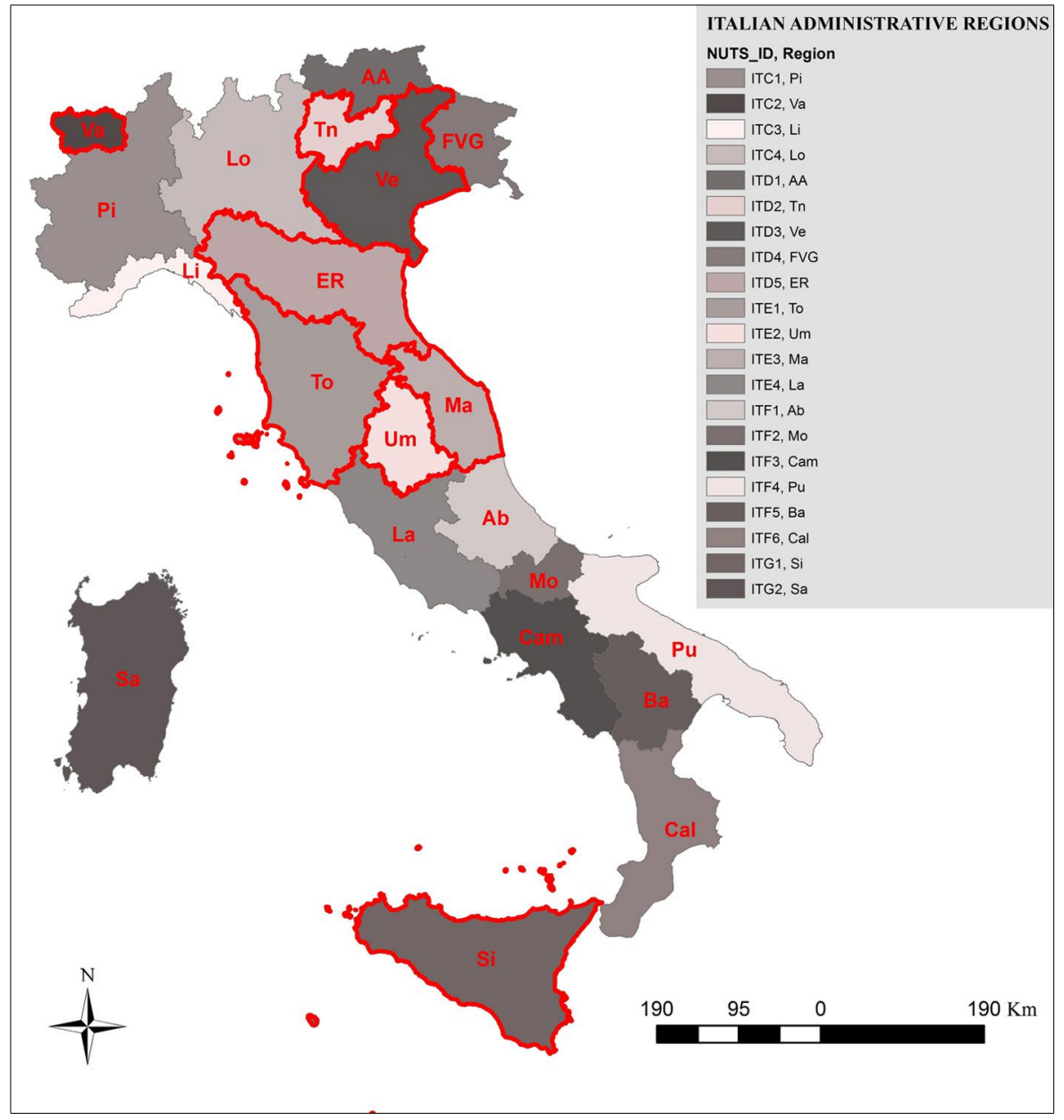

Fig. 1 - Italian administrative regions and NUTS2 code (i.e., Nomenclature of Territorial Units for Statistics). Regions highlighted by red borders were used to compare national data with regional forest inventories.

the FM area of this country (Pilli et al. 2013). Additional specific questions addressed by this study related to: (i) the impact on the AR sink of different assumptions about species composition (often not well known for many European countries) of AR areas; (ii) the potential contribution of harvest from AR lands, relative to the total harvest at the country level; (iii) the impact of forest fires on the AR sink; (iv) the comparison of AR rates estimated by the two case studies with independent sources (eight regional forest inventories and three local studies).

\section{Materials and methods}

\section{Case studies for AR annual rates}

Following the relevant IPCC guidance (IPCC 2003, 2006, 2013), to be eligible for AR activities an area of land needs to satisfy a number of criteria, including: (i) the country's definition of forest was not met on 31 December 1989; (ii) trees are growing as a result of direct human-induced activity; and (iii) the trees meet or have the potential to meet the country's definition of forest at ma- turity.

According to the Italian National Inventory Report (NIR) submitted to UNFCCC and its Kyoto protocol (Italy 2013, 2014), Italy adopted a broad definition of AR, i.e., assuming that AR included all forest expansion after 31 December 1989, including plantations and abandoned pastures and arable lands where forest expanded naturally. In this paper we do not address the criteria to be fulfilled to demonstrate that AR activities are "directly human-induced" (see IPCC 2013, section 2.5)

Until 2013, poplar plantations (considered cropland according to Italian laws) were excluded from AR (NIR 2013); the last Italian NIR (2014), submitted to UNFCCC on $15^{\text {th }}$ April 2014, included poplar plantations under AR activities. All these lands are consieven prohibiting clear cut activities on these forests (Italy 2013, 2014). Therefore, in Italy the area under $\mathrm{AR}$ in the year $i\left(A R_{\mathrm{i}}\right)$ is given by the difference between the total forest area in that year $\left(F o r_{\mathrm{i}}\right)$ and the forest area existing by 31 December 1989 (i.e., the FM dered legally bound by national legislation, area $\left.-F o r_{\mathrm{FM}}\right)$, minus the total deforestation since $1990\left(D_{\mathrm{T}}-\right.$ eqn. 1$)$ :

$$
A R_{i}=\text { For }_{i}-\text { For }_{F M}-D_{t}
$$

Due to the lack of data, the annual rate of deforestation occurring on AR cannot be estimated. According to the 2013 Italian NIR (Tab. 7.3 - Italy 2013), between 1990 and 2011 deforestation affected on average about $0.72 \mathrm{kha} \mathrm{yr}^{-1}$ (the NIR 2014 reports a higher annual rate of deforestation after 2004).

The estimates of the forest expansion can be provided by two different data sources: the Italian NIR and the Italian Land Use Inventory System (IUTI 2010, Corona et al. 2012, Marchetti et al. 2012). These two data sources were the basis for the two cases study analyzed below.

As first data source, we used the official estimates reported by Italian NIR in 2013 (Italy 2013). In this case (named "official estimates"), based on a total rate of afforestation equal to 1479 kha between 1990 and 2008 (as reported by Tab. 10.10 - Italy 2013), we estimated an average annual rate of AR between 1990 and 2005 equal to 77.8

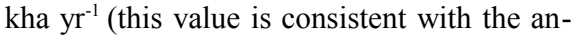
nual rates of AR reported by Tab. 7.3 - Italy 2013), assumed as a constant annual rate (excluding deforestation). On the $15^{\text {th }}$ April 2014, Italy submitted the 2014 NIR, reporting a total rate of afforestation equal to 1436 kha between 1990 and 2008 and a slightly lower AR (compared to the previous

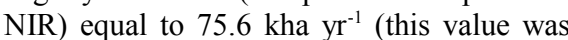
not considered by the present study).

The value reported in the NIR derives from a linear interpolation between the 2005 total forest area estimated by the last National Forest Inventory (NFI: Italian National Forest and Carbon Inventory, named INFC Gasparini \& Tabacchi 2011), and the first NFI, which refers to 1985 (MAF-ISAFA 1988).

The INFC forest area was equal to about 8759 kha (with a standard error $\mathrm{SE}=0.4 \%$ ) and was based on the FAO-FRA 2000 forest definition (i.e., a minimum forest size equal to 0.5 ha and a crown cover greater than $10 \%$ - FRA 2000). The sampling design of the INFC was based on a three-phase inventory. In the first phase, 301300 sampling points were classified by land-cover/land-use classes through ortophoto interpretation (Tabacchi et al. 2005). In the second phase, a subsample was randomly selected from forest and other wooded land strata, according to the proportion of the land-cover class reported in the 21 Italian administrative regions (Fig. 1). In this phase, approximately 30000 sample points were surveyed in the field: (i) to verify the previous classification; (ii) to discriminate forest from other wooded land; (iii) to identify different forest types (Fts); and (iv) to collect information on other 
Tab. 1 - Percentage distribution at the regional level of the total annual rates of AR applied in official estimates (assuming a fixed percentage distribution for the entire period) and in IUTI estimates (assuming different distributions before and after 2000). $\left({ }^{*}\right)$ : Due to rounding the sum may be slightly lower than $100 \%$.

\begin{tabular}{lccc}
\hline \multirow{2}{*}{ Italian Regions } & $\begin{array}{c}\text { Official estimates } \\
\text { (NIR) }\end{array}$ & \multicolumn{2}{c}{$\begin{array}{c}\text { IUT estimates } \\
\text { (IUTI) }\end{array}$} \\
\cline { 2 - 4 } & $\mathbf{1 9 9 0 - 2 0 2 0}$ & $\mathbf{1 9 9 0 - 2 0 0 0}$ & $\mathbf{2 0 0 1 - 2 0 2 0}$ \\
\hline Abruzzo & 5 & 4 & 8 \\
Basilicata & 3 & 3 & 5 \\
Calabria & 5 & 0 & 2 \\
Campania & 4 & 5 & 1 \\
Emilia-Romagna & 7 & 2 & 4 \\
Friuli-Venezia & 4 & 7 & 5 \\
Lazio & 7 & 2 & 1 \\
Liguria & 3 & 4 & 5 \\
Lombardia & 6 & 5 & 0 \\
Marche & 4 & 6 & 9 \\
Molise & 1 & 9 & 2 \\
Piemonte & 10 & 5 & 2 \\
Puglia & 2 & 9 & 8 \\
Sardegna & 6 & 4 & 0 \\
Sicilia & 3 & 8 & 20 \\
Toscana & 12 & 4 & 12 \\
Bolzano-Bozen & 4 & 11 & 9 \\
Trento & 4 & 1 & 1 \\
Umbria & 4 & 5 & 4 \\
Valle d'Aosta & 1 & 1 & 0 \\
Veneto & 5 & 4 & 2 \\
Italy* & 100 & 100 & 100 \\
\hline
\end{tabular}

qualitative attributes of the forest stands.

By applying a forest definition based on a minimum forest size equal to 0.2 ha and a crown cover greater than $20 \%$, the first Italian NFI estimated a total forest area for 1985 equal to 8675 kha $(\mathrm{SE}=0.9 \%)$, including forests, plantations and other wooded lands (MAF-ISAFA 1988). This inventory was based on approximately 30000 sample points classified as forest or non-forest by field surveys, combined with information spectively (we based this assumptions on the definition adopted by Italy until April 2014); and (ii) the area of shrub lands and other wooded lands are excluded in the first NFI, i.e., about 1475 kha. The resulting forest areas, equal to about 7089 kha in 1985 and 8693 kha in 2005, are reported in Fig. 2 (left panel).

Based on the Land Use Change Matrices for the years 1990-2011 (Tab. 7.3 - Italy 2013), the annual rate of AR slightly in-

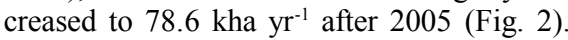
The 2014 Italian NIR reported a lower AR since 2008 , equal on average to $58.3{\mathrm{kha} \mathrm{yr}^{-1}}^{-1}$ for the period 2008-2011. This recalculation, not considered by the present study (the NIR 2014 was published in April 2014, when the draft version of this manuscript was under review), was based on new data provided by the first phase of the new Italian NFI.

The annual rate of AR based on the official

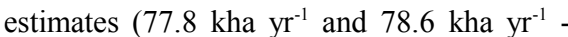
Fig. 2, right panel) was further distributed at the regional level proportionally to the total amount of AR reported for each region in the Italian NIR (see Tab. 10.10 - Italy 2013) for the period 1990-2011 (see Tab. 1). We derived from Tab. 10.10 the annual rate of AR at regional level for the periods 2008-2009 $\left(A R_{1}\right), 2009-2010 \quad\left(A R_{2}\right)$ and 2010-2011 $\left(A R_{3}\right)$, and we estimated the AR rate at regional level $\left(A R_{\%}\right)$ as follows (eqn. 2$)$ :

$$
A R_{\%}=\frac{\text { Average }\left(A R_{1}+A R_{2}+A R_{3}\right)}{\text { Average }(78.6+78.6+79.3)} \cdot 100
$$

According to De Natale et al. (2003), differences in the estimates of the forest area, related to the two forest definitions applied by the inventories, are negligible $(<1 \%)$. Therefore, the forest area estimated for 1985 can be compared with the forest area estimated for 2005 when the following conditions are met: (i) poplar plantations are excluded in both inventories, i.e., $111 \mathrm{kha}$ and $66 \mathrm{kha}$, for the first and the second NFI, re- where 78.6 and 79.3 are the total annual rate of AR in kha $\mathrm{yr}^{-1}$ reported by Tab. 10.10 for the periods 2008-2009 and 2009-2010 (78.6

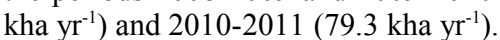

A second data source, named "IUTI estimates", was obtained from the Italian Land Use Inventory System (IUTI 2010) based on

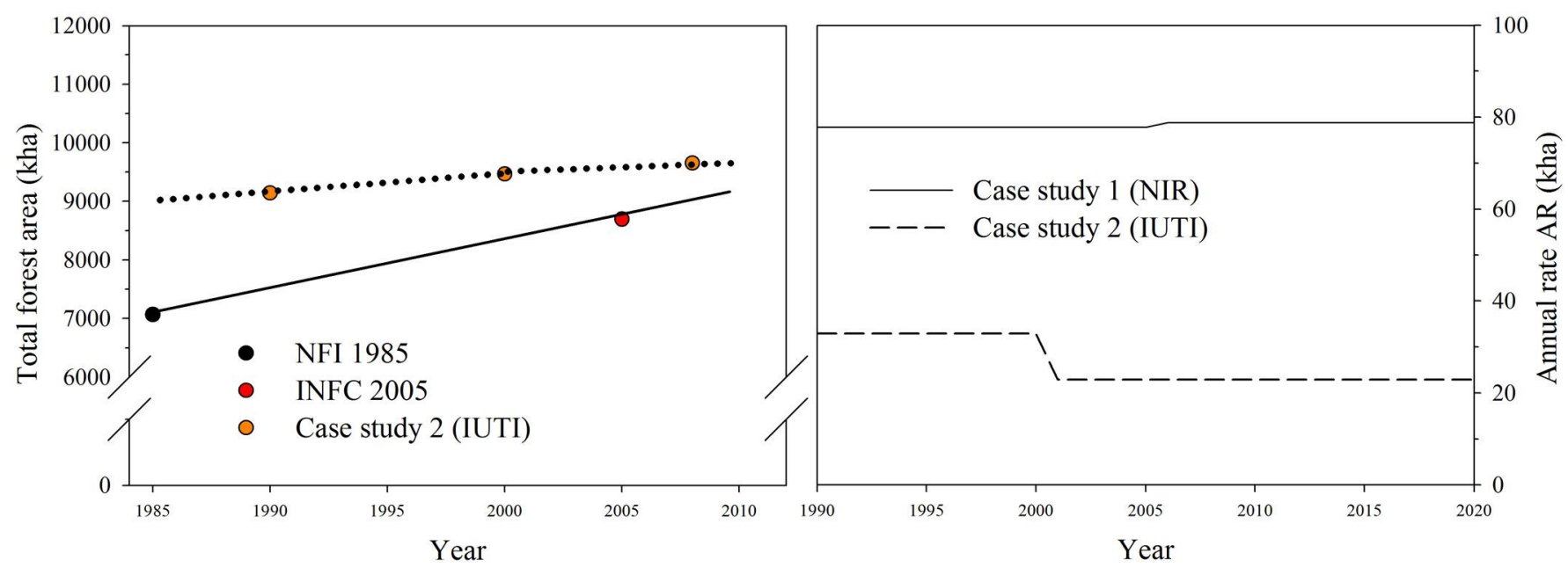

Fig. 2 - Left panel: total forest area (excluding poplar plantations, shrub land and other wooded lands) estimated by the first (NFI 1985) and the second (INFC 2005) NFI (used by official estimates) and by IUTI (IUTI estimates) and a linear interpolation between these data. Right panel: annual rate of AR applied during the model run, according to data reported by the Italian NIR (Italy 2013) and by IUTI (Corona et al. 2012, Marchetti et al. 2012). 
the visual interpretation of a set of multitemporal aerial orthophotos $(1990,2000$, 2008 and 2012). Six land-use classes (settlements, cropland, forest land, grassland, wetland and other lands) were detected on georeferenced points with no field surveys (Corona et al. 2012). The forest land definition applied by IUTI was consistent with both the FAO-FRA2000 (FRA 2000) and the INFC forest definitions (see Tab. 4). Moreover, 301300 out of 1206000 sampling points used by IUTI coincide with the points used in the first phase of the INFC.

According to Marchetti et al. (2012) the total forest land area (excluding all plantations and other wooded lands) increased from 9141 kha $\left(A_{1990}, \mathrm{SE}=0.1 \%\right)$ in 1990 to 9470 kha $(\mathrm{SE}=0.1 \%)$ in 2000 and to 9653 kha $\left(A_{2008}, \mathrm{SE}=0.1 \%\right)$ in 2008 (Fig. 2, left panel). Based on these data the annual average rate

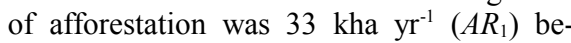
tween 1990 and 2000 and $23 \mathrm{kha} \mathrm{yr}^{-1}\left(A R_{2}\right)$ between 2000 and 2008 (see Fig. 2, right panel). The regional distribution of these values, applied to the second case study and reported in Tab. 1, can be derived from the data reported by Corona et al. (2012). The figures reported for the period 2000-2008 were assumed constant until 2020

\section{Estimation of carbon stock changes}

\section{The Carbon Budget Model}

To estimate the $\mathrm{C}$ stock change on $\mathrm{AR}$ lands, we used the Carbon Budget Model (CBM) developed by the Canadian Forest Service (Kurz et al. 2009). The model was recently applied to the Italian forests in order to estimate the $\mathrm{C}$ sink of the FM area since

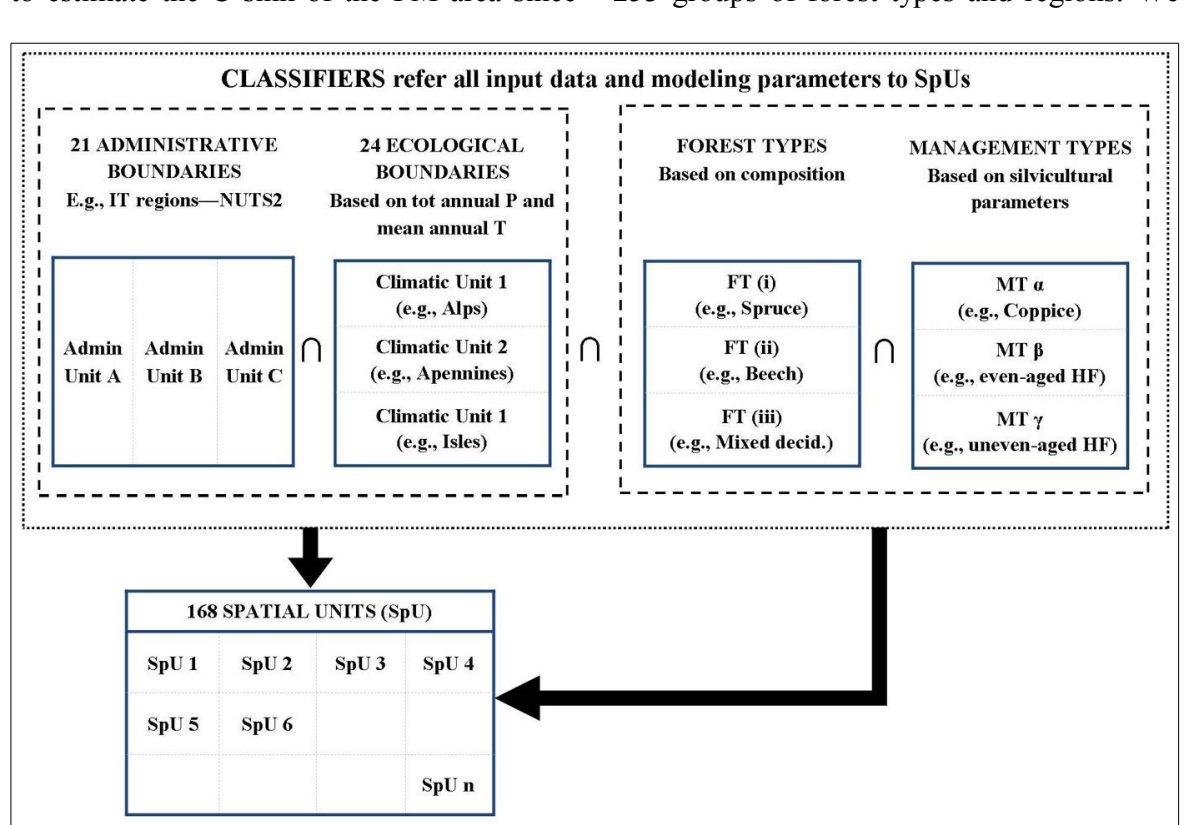

Fig. 3 - Schematic representation of the main input data required by CBM in order to define the Spatial Units (SpUs). The dashed line identifies the general classifiers and the dotted line delimits the information provided by the forest inventory, split between each $\mathrm{SpU}$ (by Pilli et al. 2013).
1995. The application of the CBM to Italian forests is described in detail by Pilli et al. (2013) and only essential details are summarized below.

The CBM is an inventory-based (i.e., it is based on the information commonly reported by national forest inventories, NFIs), yielddata driven (i.e., the estimates are mainly driven by yield data provided by the user) model that simulates the stand- and landscape-level $\mathrm{C}$ dynamics of above- and below-ground biomass, dead organic matter (DOM: litter and dead wood) and mineral soil. The main input data required by model are:

1. The area, further distinguished by age classes, main species and management types (i.e., coppices, even-aged high forests, uneven-aged high forests, etc.). Since the present study focuses on AR, we do not need to define any preliminary age class distribution and management type, but only the forest composition of the afforested area.

2. The gross merchantable volume production by age classes, main species and (eventually) management types, defined by yield tables (YTs) provided by the user. These data represent the stand-level volume accumulation in the absence of natural disturbances and management practices. Tables can be directly inferred by the volume and increment data provided from NFIs or from the literature.

The present study focuses on young (less than 30 years old) forests. However, the INFC reports increment and volume data for the age classes $<20$ years for only 39 out of 253 groups of forest types and regions. We

$$
\underset{m i n}{m}
$$
many cases the natural expansion of forests is driven (at least in the first stage) by few species with a higher seed dispersal capacity (i.e., pioneer species - Oldeman 1990) and this process may favor the formation of almost-pure forest stands (see Tab. 2 and the following section).

Specific equations were selected to fit the species-specific values of biomass reported in the INFC and to convert the merchantable volume into aboveground biomass (Boudewyn et al. 2007). A detailed analysis on the calibration of stand level equations is reported by Pilli et al. (2013, Appendix D). Belowground biomass was calculated using the equations provided by $\mathrm{Li}$ et al. (2003) and the annual dead wood and foliage input was estimated as a percentage applied to the standing biomass stock (Kurz et al. 2009).

To estimate the decomposition rate of each DOM pool, the base decomposition rates defined at $10{ }^{\circ} \mathrm{C}$ for each pool is adjusted in the CBM based on the mean annual temperature in each SPU. For forested lands, DOM pools (dead wood and litter) and soil are ini- 
tialized using a procedure that takes into consideration site productivity, temperaturedependent decomposition rates and disturbance history (Kurz et al. 2009).

For the initialization of the non-forested lands, the user can define the initial $\mathrm{C}$ content (before afforestation) of the living biomass (i.e., merchantable, foliage, roots, etc.) and DOM pools.

Forest expansion in Italy is mainly related to process of natural re-colonization of abandoned areas (Corona et al. 2005, De Natale et al. 2007, Dalla Valle et al. 2009), moving from grasslands or pastures to forested lands, through the progressive establishment of tree species. Therefore, for the initialization of the non-forested lands we assumed that:

1. the initial soil $\mathrm{C}$ stock was equal to the average soil $\mathrm{C}$ content of grassland, i.e., $78.9 \mathrm{Mg} \mathrm{C} \mathrm{ha}^{-1}$ as reported by the Italian NIR (Italy 2013);

2. the average $C$ stock of the living biomass sub-pools before AR was equal to $3 \%$ (i.e., a total living biomass $\mathrm{C}$ stock equal to 2 $\mathrm{Mg} \mathrm{C} \mathrm{ha-1)} \mathrm{of} \mathrm{the} \mathrm{average} \mathrm{C}$ stock estimated by CBM for the FM area between 1995 and 2010, as reported by Pilli et al. (2013).

The user can define annual natural and anthropogenic disturbances such as fire, insects or storms and partial or clear-cut harvesting which may be applied during the model run (Kull et al. 2011). Afforestation and deforestation can be represented as disturbance types with their own disturbance matrices and transitions to and from forest land.

The model provides annual predictions on $\mathrm{C}$ stocks and fluxes, such as the annual $\mathrm{C}$ transfers between pools, from pools to the atmosphere and to the forest product sector, as well as ecological indicators such as the net primary production. The model also reports land areas and $\mathrm{C}$ pools in the appropriate UNFCCC and KP land categories.

\section{Model scenarios}

The annual rate of afforestation reported in Fig. 2 - and distributed at the regional level according to Tab. 1 - was further distributed for both case studies between 17 FTs (see Tab. 2). Due to the different classification systems, the forest composition reported by the two inventories is not comparable. The proportion of each FT at regional level was therefore based on the FT distribution reported by INFC, taking into account the following considerations:

1. The total forest area detected by INFC can be distinguished between different management types (defined according to the silvicultural system and the forest structure): coppices (further distinguished between simple coppice, coppice with standards, coppices in transition to high forests, etc.), even-aged high forests, uneven-aged high forests, not-defined class and not-classified

Tab. 2 - Main species associated to each forest type (FT), seed dispersal capacity assigned to each FT (1: anemochory/wind-dispersed species; 0: non-anemochory species; 0.5: mixed groups of species), light tolerance index based on Ellenberg \& Leuschner (2010) and the total weighting factor (equal to the sum of the previous indexes) assigned to each forest type.

\begin{tabular}{lcccc}
\hline Main species & FT & $\begin{array}{c}\text { Seed dispersal } \\
\text { capacity }\end{array}$ & $\begin{array}{c}\text { Light } \\
\text { tolerance }\end{array}$ & $\begin{array}{c}\text { Weighting } \\
\text { factor }\end{array}$ \\
\hline Larch and stone pine forests & LD & 1.0 & 1.0 & 2.0 \\
Norway spruce forests & PA & 1.0 & 0.5 & 1.5 \\
Silver Fir forests & AA & 1.0 & 0.0 & 1.0 \\
Scots pine and Mountain pine & PS & 1.0 & 1.0 & 2.0 \\
Black pine forests & PN & 1.0 & 1.0 & 2.0 \\
Mediterranean pine forests & PM & 0.0 & 0.5 & 0.5 \\
Other coniferous forests & OC & 0.5 & 0.5 & 1.0 \\
Beech forests & FS & 0.0 & 0.5 & 0.5 \\
Oak forests (Quercus spp.) & QR & 0.0 & 1.0 & 1.0 \\
Turkey Oak forests & QC & 0.0 & 1.0 & 1.0 \\
Chestnut forests & CS & 0.0 & 0.5 & 0.5 \\
Hornbeam forests & Oca & 1.0 & 0.5 & 1.5 \\
Riparian forests & RF & 1.0 & 1.0 & 2.0 \\
Mixed deciduous broadleaved forests & OB & 0.5 & 0.5 & 1.0 \\
Holm oak forests & QI & 0.0 & 0.5 & 0.5 \\
Cork oak forests & QS & 0.0 & 0.5 & 0.5 \\
Other evergreen forests & OE & 0.5 & 0.5 & 1.0 \\
\hline
\end{tabular}

for the management type/system forest area (see Table 7.4 in Gasparini \& Tabacchi 2011).

2. We assumed that the new forests detected during the field measurements of the INFC should have been included in the not-defined class (INFC 2004). Indeed, (i) the areas classified as coppice (3673 kha and 3663 kha reported by the first and the second NFIs, respectively) and even-aged high forest (1176 kha and 1509 kha, reported by the first and the second NFIs, respectively) by the two inventories are similar; (ii) the area reported in the not-defined class by INFC (i.e., about $886 \mathrm{kha}$, also including some other forests types), covers about $55 \%$ of the total forest area established between 1985 and 2005 (i.e., about $1600 \mathrm{kha}$ ); the remaining amount of natural forest expansion (about $757 \mathrm{kha}$ ) was probably reported as not-classified for the management type/system or under some other category (i.e., uneven-aged high forests).

3. The original FTs percentage distribution estimated at the regional level and based on the not-defined plus not-classified forest area was applied to the annual rates of AR defined for the official estimates, as a first possible share of species. This distribution, named "FT distribution 1", was used to test the effect of the species composition on the model output.

4. Since the previous forest area (i.e., not-defined + not-classified group) also included some FTs with a low seed dispersal capacity, such as beech and chestnut, we further corrected the FT distribution 1 according to a weighting factor (i.e., a multiplier applied to the original distribution) based on the seed dispersal capacity and the light tolerance of each species (Tab. 2). This correction generally increased the share of larch and conifers and reduced the share of

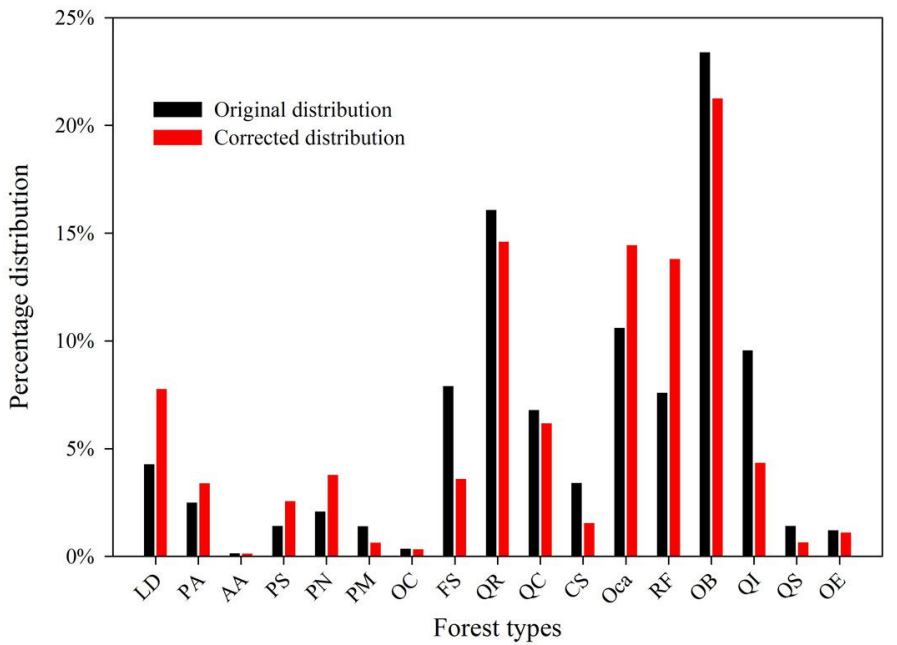

Fig. 4 - Comparison between the FT distribution 1 (based on the FT distribution of the INFC not-defined plus not-classified forest area) and the FT distribution 2 (based on the previous distribution corrected according to the weighting factors reported in Tab. 2) percentage distribution at national level. The FTs acronyms are reported in Tab. 2. 
Fig. 5 - (Upper panel): total amount of area burned (black line) reported by official statistics (CFS 2010, 2012) and used by our study to estimate the amount of AR area burned between 1990 and 2011, applied during the model run in official estimates (black line on the lower panel). The upper panel also highlights the total amount of area

burned reported by the KP LULUCF ta-

bles submitted to

UNFCCC in 2013 (green line) and

2014 (red line). The lower panel highlights the AR area burned reported by the KP LULUCF taUNFCCC in 2013 (green points) and 2014 (red points) bles submitted to

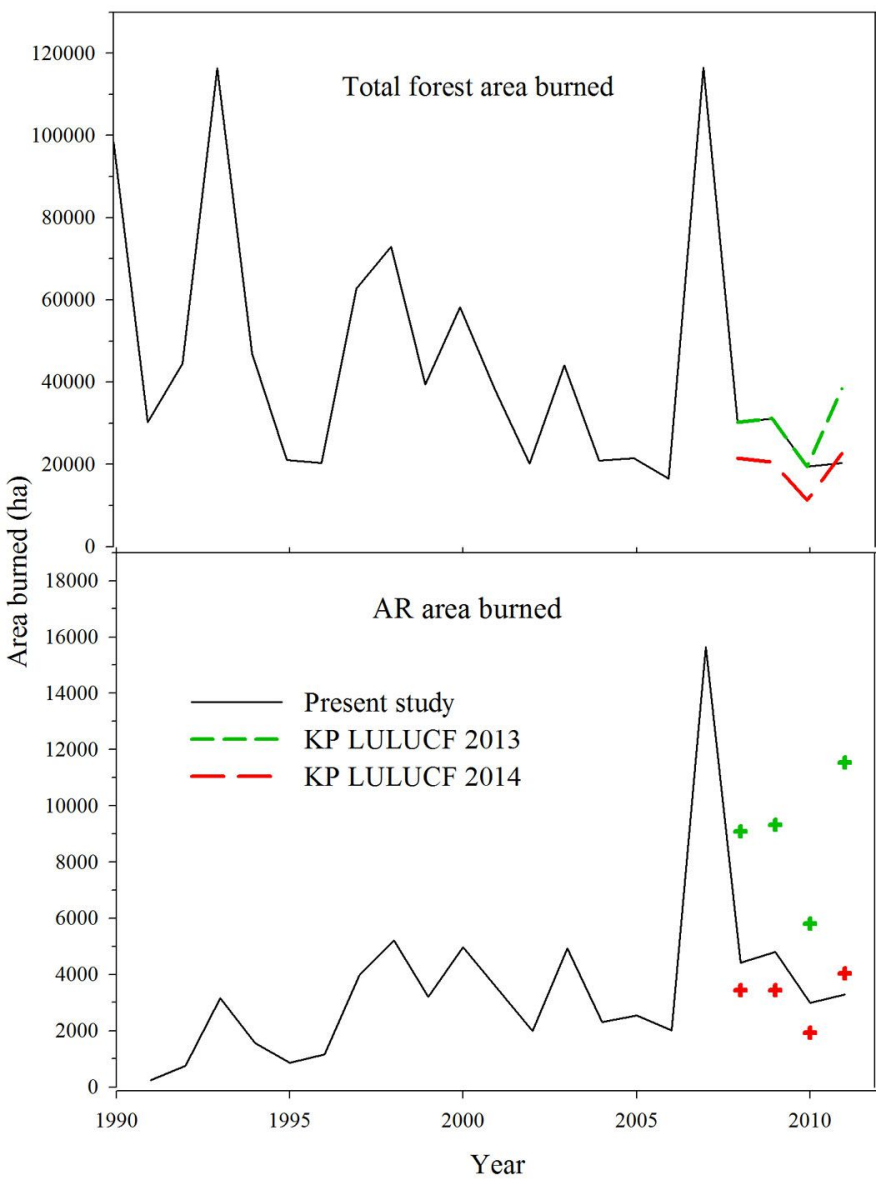

beech and chestnut (Fig. 4). The resulting FT distribution 2 was applied to the annual rate of AR defined in both case studies. A comparison between the FT distribution 1 and 2 is reported in Fig. 4.

To provide an estimate of the future potential $\mathrm{C}$ sink related to $\mathrm{AR}$, the model was run to 2020 , assuming a constant annual rate of afforestation between 2011 and 2020 (see Fig. 2). Since our study focuses on AR, deforestation was not considered. Two additional disturbances were applied to the new forest area:

(1) We estimated the potential (i.e., maximum) C stock of harvested wood products provided by AR: we applied a $15 \%$ commercial thinning rate to conifer forests older than 20 years, and a $20 \%$ commercial thinning rate to broadleaved forests older than 15 years. According to Italian law, no clearcut

Tab. 3 - Summary of the scenarios analyzed by CBM, based on different assumptions about the annual rate of AR (case studies 1 and 2), FT distribution (Original and Corrected) and disturbance events (potential harvest and fire).

\begin{tabular}{ccccc}
\hline AR assumptions & Case study & FT share & Harvest & Fire \\
\hline NIR & 1 & Corrected & No & No \\
NIR & 1 & Original & No & No \\
NIR & 1 & Corrected & Yes & No \\
NIR & 1 & Original & Yes & No \\
NIR & 1 & Corrected & Yes & Yes \\
IUTI & 2 & Corrected & No & No \\
\hline
\end{tabular}

regional level are available, to be consistent with the approach applied for the FM area, the total amount of area burned each year (reported in Fig. 5) was distributed between different regions, forest types and climatic units, according to the assumptions reported by Pilli et al. (2013). This approach was applied to the data reported in official estimates for the period 1990-2011.

A summary of the different scenarios analyzed by CBM is reported in Tab. 3 .

\section{Results and discussion}

\section{Carbon stock changes of AR land}

The $\mathrm{C}$ stock change estimated by CBM is reported in Fig. 6. The total $\mathrm{C}$ stock change estimated in 1991 (i.e., at the first time step) applying the FT distribution 2 was equal to $191 \mathrm{Gg} \mathrm{C} \mathrm{yr}^{-1}$ and $77 \mathrm{Gg} \mathrm{C}^{-1}{ }^{-1}$, using the official and the IUTI estimates, respectively. Excluding the effect of harvest, in 2011 these values grow to $2418 \mathrm{Gg} \mathrm{C} \mathrm{yr}^{-1}$ (official estimates) and $870 \mathrm{Gg} \mathrm{C}^{\mathrm{Cr}} \mathrm{r}^{-1}$ (IUTI estimates). Between 1990 and 2011, with a total amount of afforestation equal to 1640 kha (official estimates) and excluding any disturbance (i.e., no harvest and no fire), the living biomass stock (aboveground and belowground) increased on average to $957 \mathrm{Gg} \mathrm{C}$ $\mathrm{yr}^{-1}\left(0.58 \mathrm{Mg} \mathrm{C} \mathrm{ha}{ }^{-1} \mathrm{yr}^{-1}\right)$, dead wood, litter and soil increased on average to $179 \mathrm{Gg} \mathrm{C}$ $\mathrm{yr}^{-1}\left(0.11 \mathrm{Mg} \mathrm{C} \mathrm{ha}^{-1} \mathrm{yr}^{-1}\right)$ and the resulting total increase was $1136 \mathrm{Gg} \mathrm{C}^{-1}(0.69 \mathrm{Mg} \mathrm{C}$ $\left.\mathrm{ha}^{-1} \mathrm{yr}^{-1}\right)$. Applying the FT distribution 1 to official estimates and excluding any disturbance, we detected a negligible percentage difference with the FT distribution 2, equal to about $0.6 \%$ of the living biomass stock.

As expected, using IUTI estimates (excluding harvest and fire) with a total amount of afforestation in 2011 of $579 \mathrm{kha}$, we estimated a lower average $\mathrm{C}$ stock change of

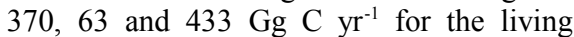
biomass, DOM and soil and total pools, respectively. This last figure is about $60 \%$ lower than the value from the official estimates.

Assuming a constant annual rate of AR after 2012 and excluding disturbance events, CBM estimated a total $\mathrm{C}$ stock change in 2020 equal to 3839 and $1298 \mathrm{Gg} \mathrm{C} \mathrm{yr}^{-1}$ in of-

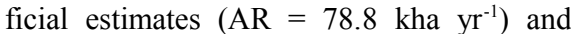

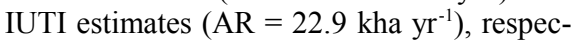
tively. Applying the FT distribution 1 to official estimates, we still detected a negligible percentage difference $(1.5 \%)$ with the FT distribution 2 for the living biomass stock in 2020.

Adding the effects of the potential harvest provided by AR land to these runs, the 2020 total $\mathrm{C}$ stock change decreased to 3237 and $1065 \mathrm{Gg} \mathrm{C} \mathrm{yr}^{-1}$, using the official and IUTI estimates, respectively. The total amount of harvest provided using the official estimates increased from about $325400 \mathrm{~m}^{3}$ in 2005 
Fig. 6 - C stock change ( $\left.\mathrm{Gg} \mathrm{C} \mathrm{yr}^{-1}\right)$ estimated by CBM for official estimates (based on the NIR's assumptions) and IUTI estimates (based on the IUTI's assumptions). The figure reports the (i) living biomass, (ii) litter, dead wood (DOM) and soil, and (iii) total C stock change, excluding distur-

bances (no harvest and no fire) and including the potential amount of harvest provided by AR (reported in the right panels in Gg of dry matter $\left.\mathrm{yr}^{-1}\right)$. The vertical dotted line in the left panels divides historical data (before 2011) and the future $\mathrm{AR}$ rate used in our study.

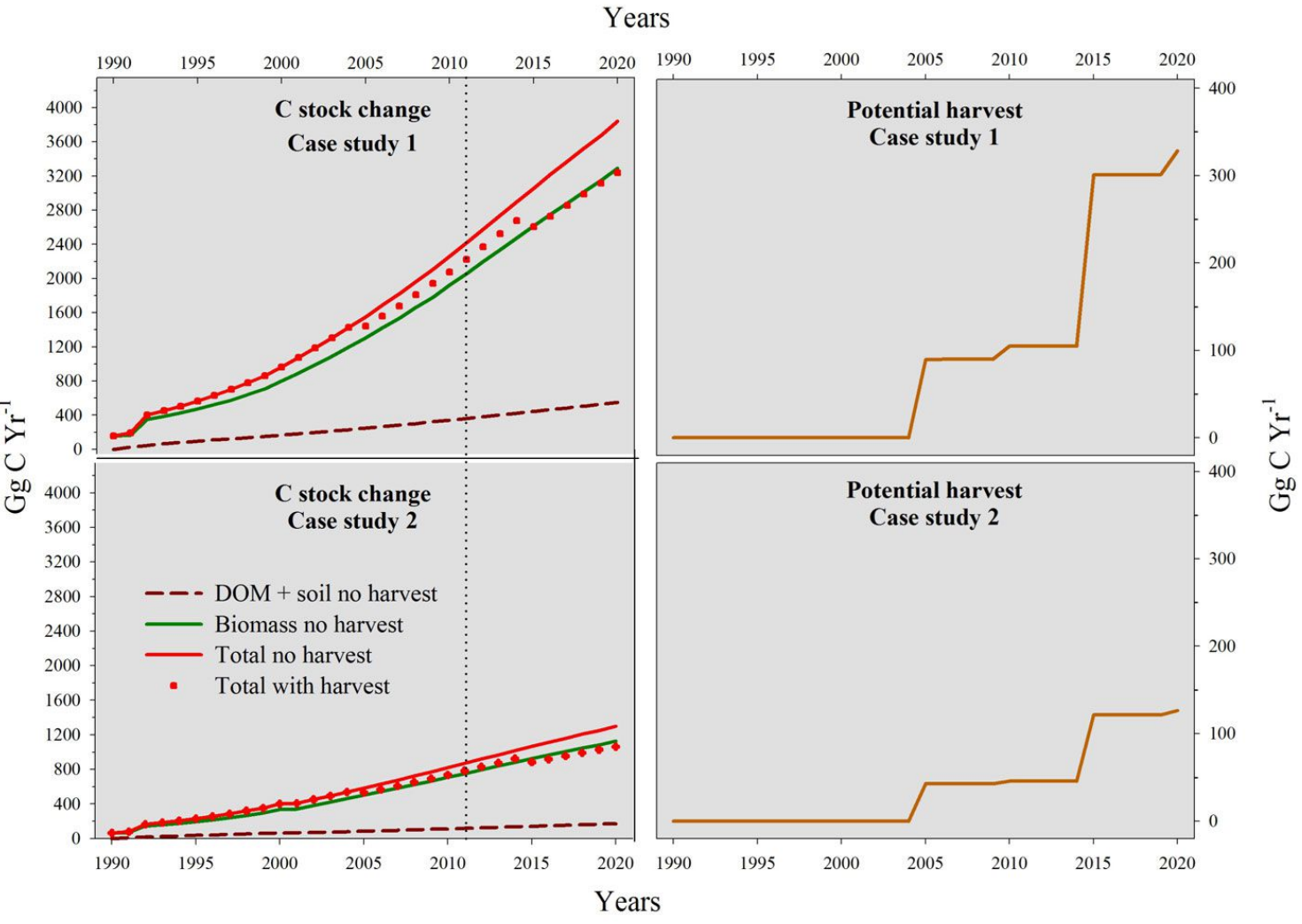

(totally provided by broadleaves) to about $1200000 \mathrm{~m}^{3}$ in 2020 . Due to our assumptions, about $85 \%$ of this amount was provided by broadleaves in 2020. This highlights that the silvicultural treatments applied to the new forest lands, excluding any kind of clearcuts, may decrease the potential 2020 C stock change by about $15-17 \%$ compared to the runs with no disturbance.

This effect was null before 2004 (Fig. 6, right panels) since we assumed that stands younger than 15 years were not affected by harvest. The harvest considerably increased after 2010, when new conifers stands (older than 20 years) were affected by commercial thinnings. In 2015 a second thinning was applied to the broadleaves area afforested in 1990 (i.e., 25 years old in 2015): this area had a first thinning in 2005, when it was 15 years old and, based on our assumptions, the same area may have a second thinning after 10 yrs. (i.e., in 2015). Since the annual rate of AR was constant between 1990 and 2005 , during the following 5 years the same amount of area is available (every year) for a second thinning applied to broadleaves. In 2020, a further increase on harvest is due to an additional amount of forest area available (both for broadleaves and for conifers) for a second thinning.

A different FT composition (based on the FT distribution 1 applied to official estimates) may reduce the total amount of harvest by less than $4 \%$ on average.

The total amount of harvest provided by
AR using the official estimates increases from about $89 \mathrm{Gg}$ of dry matter in 2005 (42.5 Gg using the IUTI estimates) to about $328 \mathrm{Gg}$ of dry matter in 2020 (127 Gg using the IUTI estimates). These figures account for about 3\% (1\% in IUTI estimates) of the total amount of harvest provided in 2005 by Italian forests, equal to about $6550 \mathrm{Gg}$ of dry matter (Pilli et al. 2013) and they only represent a potential (i.e., maximum) amount of harvest that could be provided by these new forests. This suggests that in the past 20 years the total amount of harvest at the national level was almost entirely provided by the existing forests, i.e., the FM area. The contribution of harvest from AR is also likely relatively small for the near future: assuming for 2020 a level of harvest of about 15 million of $\mathrm{m}^{3}$ at the country level (Pilli et al. 2013), the future contribution from AR appears to be approximately $8 \%$. Of course, our assumptions did not consider the site productivity and other parameters (such as accessibility, slope, etc.) further reducing the potential amount of harvest provided by AR. The future harvest assumed by Pilli et al. (2013) is consistent with the assumption made by Italy for the Forest Management Reference Level.

The possible amount of harvest provided by plantations is also small. Indeed, the total amount of plantations (excluding poplar) reported at the national level by INFC is equal to about $56 \mathrm{kha}$. The inventory also detected the total amount of plantations (including poplars) established after 1990 equal to about $60 \%$ of the amount of plantations (accounting also for the not classified area). This suggests that, even assuming that these new forests are totally represented by notpoplar plantations, the total amount of plantations established between 1990 and 2005 is equal to about $33 \mathrm{kha}$, i.e., less than $3 \%$ of the total amount of AR estimated by NIR until 2005.

In order to directly compare our results with the values reported by NIR, we reported in Fig. 7 the total $\mathrm{C}$ sink estimated by $\mathrm{CBM}$ in $\mathrm{Gg} \mathrm{CO}_{2} \mathrm{yr}^{-1}$ (according to IPCC reporting guidelines negative values represent a terrestrial $\mathrm{C}$ sink and positive values a $\mathrm{C}$ source). The effect of fire emissions on AR does not considerably decrease the total $\mathrm{C}$ sink estimated by CBM in official estimates. The average $\mathrm{C}$ sink estimated to 2012, was equal to $-4396 \mathrm{Gg} \mathrm{CO}_{2}$ and $-4167 \mathrm{Gg} \mathrm{CO}_{2}$, excluding any disturbance event and including harvest and fire, respectively. As expected, since the total amount of afforested area and the amount of $\mathrm{C}$ accumulated on this area increase with time, so do the emissions related to fire on AR land. In 2007, when the total amount of burned area at the national level was equal to about $116 \mathrm{kha}$ and, according to our assumptions, $15 \mathrm{kha}$ of the AR area burned, fire emissions on AR were about $400 \mathrm{Gg} \mathrm{CO}_{2}$ eq.

In Fig. 7, the estimates provided by CBM are compared with the figures reported by Italy in the KP LULUCF tables (Tab. 5(KP- 


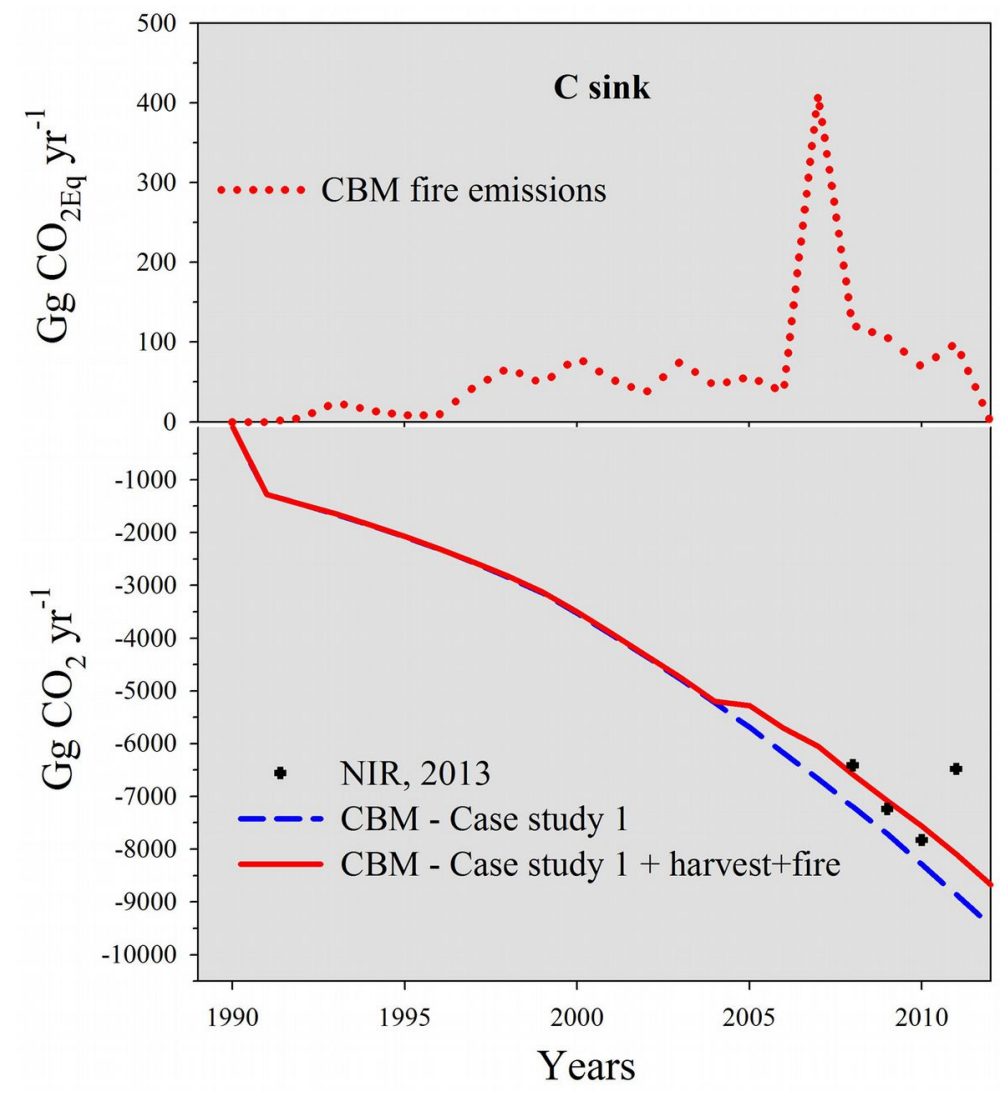

Fig. 7 - Comparison between the total $\mathrm{C}$ sink (in $\mathrm{Gg} \mathrm{CO}_{2} \mathrm{yr}^{-1}$ ) estimated by $\mathrm{CBM}$ with the official estimates (based on NIR assumptions, Italy 2013), excluding the harvest (dashed line) and including the effect of harvest and fires (red line). The figure also reports the emissions (in $\mathrm{CO}_{2 \mathrm{Eq}}$, upper panel) related to fire disturbances on the afforested area. Due to the different assumptions about the annual rate of AR, the data reported by the official estimates cannot be compared with IUTI estimates. According to the IPCC Guidance (IPCC 2013) negative values highlight a $\mathrm{C}$ sink and positive values a $\mathrm{C}$ source to the atmosphere.

Tab. 4 - Reference year and main parameters defining the forest definition (minimum area, forest cover, width and potential tree height) applied by the National forest inventories, by IUTI and by the regional inventories reported in Tab. 3. Further information on the data sources is reported in the last column. (1): the regional forest area reported includes coppices, high forests, plantations and temporary gaps; (2): the regional forest area reported includes coppices, high forests and plantations; (3): the area reported for 1992 includes only the productive forests.

\begin{tabular}{|c|c|c|c|c|c|c|}
\hline Inventory & 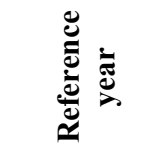 & 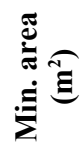 & 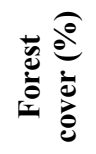 & 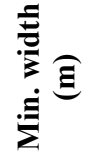 & 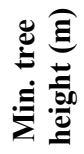 & Reference \\
\hline INFC & 2005 & 5000 & 10 & 20 & 5 & Gasparini \& Tabacchi $2011^{(1)}$ \\
\hline NFI & 1985 & 2000 & 20 & 20 & - & Castellani et al. $1988^{(2)}$ \\
\hline IUTI & $\begin{array}{l}1990,2000, \\
2008\end{array}$ & 5000 & 10 & - & 5 & $\begin{array}{l}\text { Corona et al. 2012, } \\
\text { Marchetti et al. } 2012\end{array}$ \\
\hline Emilia Romagna & 1985 & 5000 & 10 & 20 & 5 & $\begin{array}{l}\text { Regione Emilia Romagna } \\
2008\end{array}$ \\
\hline Marche & 2000 & 2000 & 20 & 20 & - & Regione Marche 2008 \\
\hline Sicilia & 2009 & 5000 & 10 & 20 & 5 & Regione Sicilia 2014 \\
\hline Toscana & 1991-1993 & 5000 & 10 & 20 & 5 & Puntelli $2009^{(3)}$ \\
\hline Trentino & 2003 & 5000 & 10 & 20 & 5 & Tonolli \& Salvagni 2007 \\
\hline Umbria & 1991 & 2000 & 20 & 20 & - & Regione Umbria 2014 \\
\hline Val d'Aosta & 1993 & 2000 & 20 & 20 & - & Pasquettaz 2014 \\
\hline Veneto & 1986 & 5000 & 10 & 20 & 5 & Anfodillo et al. 2006 \\
\hline
\end{tabular}

I) A.1.1) submitted to UNFCCC in 2013 and 2014 (UNFCCC 2013, 2014). The country's estimates on the living biomass are based on the For-est model also applied to the FM area (Federici et al. 2008). In this model, the initial growing stock volume is based on the 1985 NFI data; the biomass current annual increment is computed through derivative Richard's functions derived by an Italian yield table collection, further corrected to account for losses due to harvest, mortality and fire; dead wood and litter $\mathrm{C}$ pools are estimated using country specific emission factors and equations correlated to the living biomass pool (Italy 2013).

For the period 2008-2010, including the effect of fire and harvest (red line in Fig. 7), our estimates are consistent with those reported by Italy (UNFCCC 2013, 2014). For 2011, Italy reported a marked reduction of the total C sink (-20\% compared to 2010$)$, not estimated by our model. Due to the relevant recalculations reported by the NIRs 2013 and 2014, we cannot clearly identify the reason of this reduction. Indeed, (i) in 2013 and 2014 there was some relevant recalculation on the litter and dead wood $\mathrm{C}$ pools (Italy 2013, 2014); (ii) in 2014 there was a relevant recalculation (about $-25 \%$ compared with NIR 2013) of the AR annual rate, due to the data provided by the new NFI and to the inclusion of poplar plantations into forest (Italy 2014); (iii) between 2013 and 2014, the total burned forest area and the AR burned area reported by Italy for the period 2008-2011 considerably decreased (see Fig. 5, based on data reported by Tab. 5(KP-II) 5 of the KP LULUCF submissions 2013 and 2014). Despite these recalculations, the KP LULUCF tables submitted in 2013 and 2014 report the same C sink for the period 2008-2011, with a percentage difference lower than $2 \%$ between the values reported by the two submissions. Therefore, we can speculate that: (i) the reduction on the total C sink reported in the $2013 \mathrm{KP}$ LULUCF tables may be due to a higher burned area $(+251 \%$ compared with our assumptions); (ii) the reduction on the total $\mathrm{C}$ sink reported in the 2014 KP LULUCF tables may be due to the lower annual rate of AR assumed in 2014 (about -25\% compared with our assumptions), while the AR burned area reported by these tables is consistent with our assumptions (Fig. 5, lower panel). Despite the different AR rates and burned area, however, the estimates provided by our model, by the 2013 KP LULUCF tables and the 2014 KP LULUCF tables for the period 2008-2010 are still quite similar. This suggests that further parameters, related for example to different implied emissions factors, are involved.

Other differences may be due to the effect of fire on the dead wood and litter pools. Indeed, as highlighted for the FM area, due to 
the approach applied by Italy (based on a linear regression with the aboveground biomass), a reduction in biomass $\mathrm{C}$ pool due to fire causes a corresponding reduction in the dead wood pool which represents an immediate release to the atmosphere. In the CBM model, fire disturbances move part of the living biomass to the dead wood pool where it will slowly be released to the atmosphere through decay (Pilli et al. 2013).

\section{Annual rate of $A R$}

The differences between the annual rates of AR based on the official estimates and IUTI reflect the difference in the trend of total forest area reported by the two NFIs (used by official estimates) and estimated by IUTI. For IUTI, based on the data reported by Marchetti et al. (2012), the total forest area in $1985\left(A_{1985}\right)$ can be estimated as (eqn. 4):

$$
\begin{aligned}
A_{1985} & =A_{1990}-\left(A R_{1} \cdot 5\right)= \\
& =9479-(33 \cdot 5)=9305 \mathrm{kha}
\end{aligned}
$$

where $A_{1990}$ is the forest area in 1990 and $A R_{1}$ the annual rate of afforestation for the period 1990-2000. Applying the same approach to $A_{2005}$ (9653 kha) and $A R_{2}$ (23 kha), the total forest area estimated by the IUTI for 2005 $\left(A_{2005}\right)$ is equal to about $9584 \mathrm{kha}$.

By contrast, the forest area estimated by the NFIs, excluding shrub lands, other wooded lands and poplar plantations, is equal to 7089 kha (i.e., $-24 \%$ compared with $\left.A_{1985}\right)$ and 8693 kha (i.e., $-9 \%$ compared with $\left.A_{2005}\right)$ for 1985 and 2005, respectively. Therefore, the difference in annual rates of AR provided by the two studies is mainly related to the higher $(+24 \%)$ amount of forest area estimated by the IUTI for 1990 and, derived from this, for 1985 (see Fig. 2). In contrast, the difference on 2005 forest area is lower $(<10 \%)$ and probably related to different methodological assumptions, as discussed by Marchetti et al. (2012).

Since both these studies also provide detailed information at the regional level, the total forest area reported for 1985 (by the first Italian NFI), 1990 (by IUTI), 2000 (by IUTI), 2005 (by INFC) and 2008 (by IUTI) can be compared with the estimates provided by regional forest inventories available for 8 of 21 administrative regions (Fig. 1). As highlighted in Fig. 8, for all these regions the differences between the NFI's forest area and the IUTI's forest area are higher for 1990 and 2000, and are lower for 2005 and 2008. From this figure it emerges also a much higher AR rate (i.e., slope of the lines) in the NIR approach compared to IUTI.

Despite the differences in the forest definitions applied at the regional level (reported in Tab. 4 and largely discussed by Tosi \& Marchetti 1998 and Tosi \& Monteccone 2004), the forest areas estimated by the regional forest inventories are generally con-

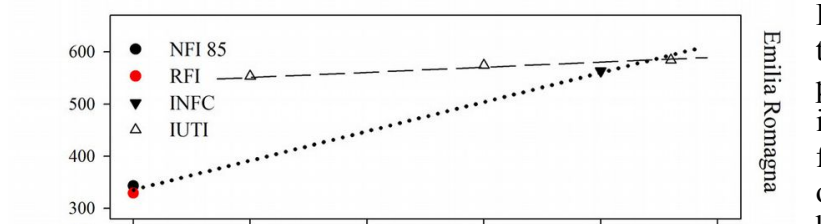

Fig. 8 - Comparison between the forest area reported by 8 regional forest inventories (RFI), by the first (NFI 85) and the second (INFC) Italian NFIs and by IUTI (for 1990, 2000 and 2008). The dotted line high-

3 lights the linear interpola-

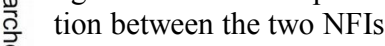

(approach used by the NIR) and the dashed lines highlight the linear interpolations between the 1990-

2000 and the 2000-2008

를. IUTI estimates. Tab. 4 reports further details on the reference year and the forest definition applied by each study.

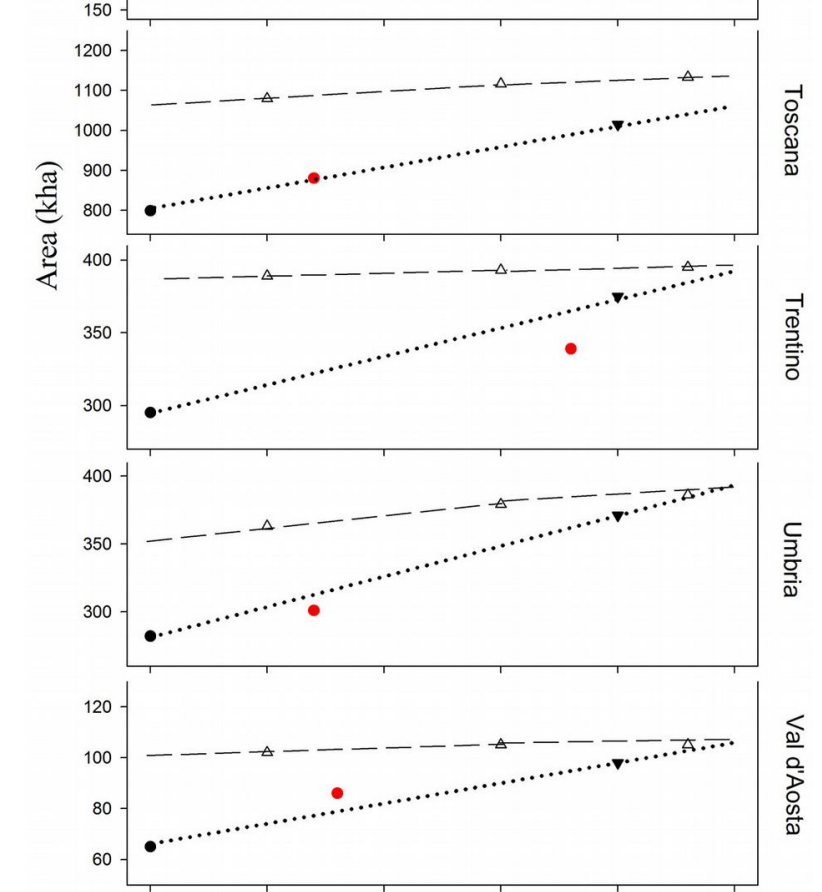

\section{$\stackrel{\overline{\vec{D}}}{\stackrel{7}{\vec{\Xi}}}$}

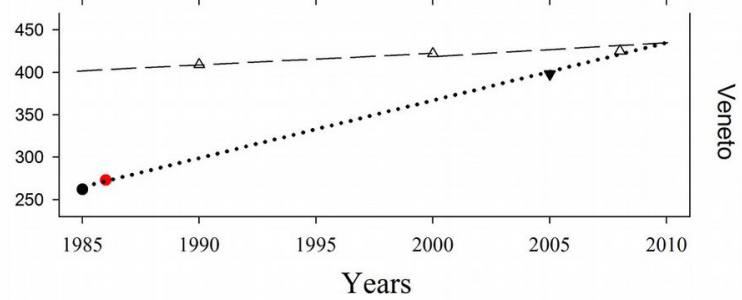

sistent with the estimates provided by the NFIs or with the linear interpolation between the 1985 and 2005 figures (dotted lines in Fig. 8). This suggests that the differences in the estimates of the forest area related to the two forest definitions are negligible, as suggested by De Natale et al. (2003). In contrast, for all these regions we detected larger differences in the estimates provided by IUTI (especially for 1990) with the linear interpolation between these data (dashed lines in Fig. 8). As discussed by Marchetti et al.
(2012), these differences may be related to the lack of a field survey in IUTI to distinguish forests and other wooded lands; by contrast, the estimates of forest area provided by the two Italian NFIs are based on field surveys, which are the sole source of information in the first NFI and a key data source in the second NFI (Tabacchi et al. 2005). This may help to explain a possible overestimation of the total forest area reported by IUTI for 1990 and a consequent lower estimate of the annual rate of AR since 
1990.

The different AR rates could also be partially due to a possible underestimation of the 2005 forest area reported by the second $\mathrm{NFI}$, due to the omission, in the second stage of the INFC, of field surveys on points classified as not-forested during the first stage (Marchetti et al. 2012). However, to avoid this underestimation of the forest area as a consequence of the lack of field surveys on non-forest sampling units, the second NFI implemented a procedure to control omission classification errors referred to forest sampling units that would not be classified as forest in the first phase (Gasparini \& Tabacchi 2011, p. 29).

Furthermore, the localization of the forest border, the possibility to distinguish young trees from shrubs in orthophotos, the question whether actual or potential minimum tree heights are assessed, the training of the personnel conducting the assessments, as well as other issues specified in the field protocols and assessment instructions, have to be considered in an exhaustive comparison of the two studies (Tab. 4).

Additional information to analyze AR estimates of NIR and IUTI is provided by three local studies on forest expansion. For the Trentino region, De Natale et al. (2007) estimated an annual rate of forest expansion equal to $0.11 \%$ for the period $1973-1999$; for the Abruzzo region, Corona et al. (2005) estimated an annual rate of forest expansion equal to $0.23 \%$ for the period $1990-2002$; for the Veneto region, Salvadori et al. (2006) and Dalla Valle et al. (2009) estimated an annual rate of forest expansion between $0.04 \%$ and $0.26 \%$ for the period $1991-2003$. All these estimates are considerably lower than the values inferred by NFI data (i.e., $0.64 \%, 0.75 \%$ and $0.37 \%$, for Trentino, Abruzzo and Veneto region, respectively), but sometimes higher also than the values detected from IUTI. These differences may be also due to the specific methodological assumptions of these studies:

1. The observation period is different and particularly for the Trentino region the initial year (1973) could affect the resulting $\mathrm{AR}$, as afforestation is not a linear phenomenon.

2. The case study of Veneto is limited to a portion of the region.

3 . The three studies are based on photointerpretation without field data, and the diachronic classification of the ortophotos could have led to an overestimation of forest area for the past.

Overall, the comparison of AR rates reported by the 2013 NIR and IUTI with other independent sources for the period 19902005 gives mixed results: the regional forest inventories seem to support the AR rates reported by the NIR, while the local studies suggest AR rates somehow intermediate be- tween NIR and IUTI. Based on the data provided by IUTI, recently confirmed by the preliminary results provided by the new Italian NFI, it is likely that the annual rate of AR in Italy in the last decade is decreasing compared with the ' $80 \mathrm{~s}$ and the ' 90 s.

\section{Conclusions}

We used the CBM to estimate the $\mathrm{C}$ stock changes resulting from AR activities in Italy for the period 1990-2020, including the potential effect of harvest and natural disturbances. We ran the model for two cases studies, based on different sources of data: an average annual rate of AR of about 78 kha $\mathrm{yr}^{-1}$ (using the 2013 official estimates, reflecting the Italian National Inventory Re-

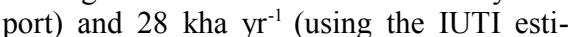
mates, based on Italian Land Use Inventory System). Furthermore, we compared these two different $A R$ rates with independent sources: eight regional forest inventories and three local studies.

The average $\mathrm{C}$ stock change estimated by our model between 1990 and 2020, excluding harvest or natural disturbances, averaged $1738 \mathrm{Gg} \mathrm{C} \mathrm{yr}^{-1}$ (official estimates) and $630 \mathrm{Gg} \mathrm{C} \mathrm{yr}^{-1}$ (IUTI estimates). The results based on the official estimates are consistent with the estimates reported by Italy for the period 2008-2010. Due to a different amount of area burned and AR rate, as well as to different model assumptions on the dead wood and litter pools, the $\mathrm{C}$ sink estimated by CBM for 2011, was about $20 \%$ lower than the $\mathrm{C}$ sink reported by the KP LULUCF tables (UNFCCC 2013, 2014).

Furthermore, our analysis suggests that:

1. the rates of $A R$ are a major source of uncertainty in the estimation of AR stock changes; CBM results are comparable with NIR's ones when the same AR rate is used;

2. the different assumptions about the forest composition of AR area have a small impact on estimates of the AR sink;

3. due to the young age of the new forests, the potential amount of harvest provided from AR land has been negligible for the historical period (likely less than $3 \%$ of the total harvest in 2005) and is expected to be small in the near future (up to about $8 \%$ in 2020);

4. forest fires for the historical period, distributed by year according to the relative proportion of the AR area compared to the total forest area, had a relatively small impact on the AR sink (on average, emission from forest fires were less than $5 \%$ of the sink);

5. the selection of the yield tables applied by the model was based on the volume data reported by the INFC for even-aged forest; the same selection could also be based on increment data reflecting the current growth of forest, but this requires more specific information on these stands;
6. the comparison of NIR and IUTI estimates for AR with eight regional forest inventories confirms the afforestation rate of NIR for the period 1990-2005, while the comparison with three local studies suggests $\mathrm{AR}$ rates somehow intermediate between NIR and IUTI; based on the data provided by IUTI, recently confirmed by the preliminary data provided by the new Italian NFI, it is likely that the annual rate of AR in Italy in the last decade is decreasing compared with the ' 80 s and the ' 90 s.

In conclusion, this study suggests that the CBM can be applied at the country level to estimate the $\mathrm{C}$ stock change related to $\mathrm{AR}$, including the effect of harvest and natural disturbances, even if only a comparison with results based on direct field measurements could verify the model's capability to estimate the real $\mathrm{C}$ stock change.

\section{Acknowledgements}

We thank Marina Vitullo (Italian Institute for Environmental Protection and Research) for the useful comments and suggestions for improving this paper and Raoul Abad-Vinas (Joint Research Center) for the support provided to analyses the NIR and KP LULUCF tables. We also thank two anonymous reviewers who provided useful suggestions to improve the manuscript.

The views expressed are purely those of the authors and may not in any circumstances be regarded as stating an official position of the European Commission or Natural Resources Canada.

\section{References}

Anfodillo T, Pilli R, Salvadori I (2006). Indagine preliminare sullo stock di Carbonio nelle foreste del Veneto [Preliminary Investigation on the Forest Carbon Stock of Veneto Region]. Regione del Veneto, Venice, Italy, pp. 125. [in Italian] Boudewyn P, Song X, Magnussen S, Gillis MD (2007). Model-based, volume-to-biomass conversion for forested and vegetated land in $\mathrm{Ca}$ nada. Inf. Rep. BC-X-411, Pacific Forestry Centre, Canadian Forest Service, Victoria, Canada, pp. 112. [online] URL: http://cfs.nrcan.gc.ca/ publications $/$ ? id $=27434$

Böttcher H, Verkerk PJ, Mykola G, Havlik P, Grassi G (2012). Projection of the future EU forest $\mathrm{CO}_{2}$ sink as affected by recent bioenergy policies using two advanced forest management models. GCB Bioenergy 4 (6): 773-783. - doi: 10.1111/j.1757-1707.2011.01152.x

Castellani C (1982). Tavole stereometriche ed alsometriche costruite per boschi italiani [Stereometric and alsometric tables built for Italian forests]. Istituto Sperimentale per l'Assestamento Forestale e l'Alpicoltura, Trento, Italy, pp. 158. [in Italian]

Castellani C, Scrinzi GF, Tabacchi G, Tosi V (1988). Inventario Forestale Nazionale. Sintesi metodologica e risultati. [National forest inventory. Methodological synthesis and results]. Mi- 
nistero dell'Agricoltura e delle Foreste. Istituto Sperimentale per l'Assestamento forestale e per 1'Alpicoltura, Trento, Italy. [in Italian]

CFS (2010). Incendi boschivi [Forest fires]. Web site, Corpo Forestale dello Stato, Ministero delle Politiche Agricole, Alimentari e Forestali, Rome, Italy. [in Italian] [online] URL: http://www.corpoforestale.it/flex/cm/pages/ServeBLOB.php/L/I T/IDPagina/3888

CFS (2012). Relazione sull'attività operativa del CFS nell'anno 2012 [Report on the operational activity of the National Forest Administration in 2012]. Web site, Corpo Forestale dello Stato, Rome, Italy. [in Italian] [online] URL: http:// www.corpoforestale.it/flex/cm/pages/ServeBLO B.php/L/IT/IDPagina/9098

Corona P, Pompei E, Scarascia Mugnozza G (2005). Probabilistic assessment of the rate of forest expansion in Abruzzo. Forest@ 2 (2): 178184. [in Italian with English abstract] - doi: 10.3832/efor0283-0020178

Corona P, Barbati A, Tomao A, Bertani R, Valentini R, Marchetti M, Fattorini L, Perugini L (2012). Land use inventory as framework for environmental accounting: an application in Italy. iForest 5: 204-209. - doi: 10.3832/ifor0625-005 Dalla Valle E, Lamedica S, Pilli R, Anfodillo T (2009). Land use change and forest carbon sink assessment in an alpine mountain area of the Veneto region (northeast Italy). Mountain Research and Development 29 (2): 161-168. - doi: 10.1659/mrd.1071

De Natale F, Gasparini P, Puzzolo V, Tosi V (2003). Stima del grado di copertura forestale da ortofoto e applicazione della definizione di bosco negli inventari forestali [Estimation of the degree of forest cover from orthophotos and application of the forest definition to National Forest Inventories]. L'Italia Forestale e Montana 56 (4): 289300. [in Italian]

De Natale F, Gasparini P, Carriero A (2007). A study on tree colonization of abandoned land in the Italian Alps: extent and some characteristics of new forest stands in Trentino. In: "Sustainable Forestry from Monitoring and Modelling to Knowledge Management and Policy Science" (Reynolds KM, Thomson AJ, Köhl M, Shannon MA, Ray D, Rennolls K eds). UH, Cambridge, UK, pp. 269-284.

Ellenberg H, Leuschner C (2010). Vegetation mitteleuropas mit den Alpen [Vegetation of Central Europe and the Alps]. Verlag Eugen Ulmer, Stuttgart, Germany, pp. 109. [in German]

EU (2013). The EU GHG Inventory 1990-2011. Web site, European Union, United Nations Fremawork Convention on Climate Change, Bonn, Germany. [online] URL: http://unfccc.int/national_reports/annex_i_ghg_inventories/items/27 15.php

Federici S, Vitullo M, Tulipano S, De Lauretis R, Seufert G (2008). An approach to estimate carbon stocks change in forest carbon pools under the UNFCCC: the Italian case. iForest 1: 86-95. doi: 10.3832/ifor0457-0010086

FRA (2000). FRA 2000. On definitions of forest and forest change. Forest Department, Food and
Agriculture Organization of the United Nations, Rome, Italy, pp. 14. [online] URL: ftp://ftp.fao. org/docrep/fao/006/ad665e/ad665e00.pdf

Gasparini P, Tabacchi G (2011). L'inventario nazionale delle foreste e dei serbatoi forestali di carbonio - INFC 2005. Secondo inventario forestale nazionale italiano. Metodi e risultati [The National Forest and Carbon Inventory - INFC 2005. Second Italian National Forest Inventory. Methods and results]. Ministero delle Politiche Agricole, Alimentari e Forestali, Corpo Forestale dello Stato, Consiglio per la Ricerca e la Sperimentazione in Agricoltura, Unità di Ricerca per il Monitoraggio e la Pianificazione Forestale, Edagricole-Il Sole 24 ore, Milano, Italy, pp. 653. [in Italian]

Grassi G (2012). LULUCF: major step in Durban. EFI Newsletter 1: 10-11.

Grassi G, den Elzen MG, Hof AF, Pilli R, Federici S (2012). The role of the land use, land use change and forestry sector in achieving Annex I reduction pledges. Climatic Change 115 (3-4): 873-881. - doi: 10.1007/s10584-012-0584-4

Hoogmoed M, Cunningham S, Thomson J, Baker P, Beringer J, Cavagnaro T (2012). Does afforestation of pastures increase sequestration of soil carbon in Mediterranean climates? Agriculture, Ecosystems and Environment 159: 176183. - doi: 10.1016/j.agee.2012.07.011

INFC (2004). Manuale di campagna per i rilievi di seconda fase [Field manual for the second phase surveys]. Inventario Nazionale delle Foreste e dei Serbatoi Forestali di Carbonio, Istituto Sperimentale per l'Assestamento Forestale e per l'Alpicoltura, Trento, Ministero per le Politiche Agricole e Forestali, Corpo Forestale dello Stato, Rome, Italy, pp. 182. [in Italian]

IPCC (2003). Good practice guidance for land use, land-use change and forestry (Penman J, Gytarsky M, Hiraishi T, Krug T, Kruger D, Pipatti R, Buendia L, Miwa K, Ngara T, Tanabe K, Wagner $\mathrm{F}$ eds). Institute for Global Environmental Strategies, Hayama, Japan, pp. 3.1-3.272.

IPCC (2006). Guidelines for national greenhouse gas inventories (vol. 4). Agricolture, forestry and other land use (Eggleston S, Buendia L, Miwa K, Ngara T, Tanabe K eds). Institute for Global Environmental Strategies, Hayama, Japan, pp. 4.14.83 .

IPCC (2013). Revised supplementary methods and good practice guidance arising from the Kyoto protocol (Hiraishi T, Krug T, Tanabe K, Srivastava N, Jamsranjav B, Fukuda M, Troxler $\mathrm{T}$ eds). Institute for Global Environmental Strategies, Hayama, Japan, pp. 268.

Italy (2013). Italian greenhouse gas inventory 1990-2011. Report 2013. National Inventory Report, Istituto per la protezione e la ricerca ambientale, Ispra, VA, Italy. [online] URL: http://unfccc.int/national reports/annex i ghg inventories/national_inventories_submissions/items/738 3.php

Italy (2014). Italian greenhouse gas inventory 1990-2012. Report 2014. National Inventory Report, Istituto per la protezione e la ricerca ambientale, Ispra, VA, Italy. [online] URL: http://un- fccc.int/national_reports/annex_i_ghg_inventories/national inventories submissions/items/738 3.php

IUTI (2010). Italian land use inventory system. Web site, Geoportale Nazionale, Ministero dell'Ambiente, Rome, Italy. [online] URL: http:// www.pcn.minambiente.it/catalogo/metadatoFul1.html?_cache $=$ yes $\& d o c=/ \mathrm{db} / \mathrm{metadati} / \mathrm{pcn} / \mathrm{rndt}$ $\mathrm{m}$ amte META270.xml

Karjalainen T, Pussinen A, Liski J, Nabuurs GJ, Erhard M, Eggers T, Sonntag M, Mohren G (2002). An approach towards an estimate of the impact of forest management and climate change on the European forest sector carbon budget: Germany as a case study. Forest Ecology and Management 162 (1): 87-103. - doi: 10.1016/ S0378-1127(02)00052-X

Kull S, Kurz WA, Rampley G, Morken S, Metsaranta ET, Neilson ET, (2011). Operationalscale carbon budget model of the canadian forest sector (CBM-CFS3) version 1.2: user's guide. Northern Forestry Centre, Canadian Forest Service, Edmonton, Alberta, Canada, pp. 344.

Kurz W, Dymond C, White T, Stinson G, Shaw C, Rampley G, Smyth C, Simpson B, Neilson E, Trofymow J, Metsaranta J, Apps M (2009). CBM-CFS3: A model of carbon-dynamics in forestry and land-use change implementing IPCC standards. Ecological Modelling 220 (4): 480504. - doi: 10.1016/j.ecolmodel.2008.10.018

Li Z, Kurz WA, Apps MJ, Beukema SJ (2003). Belowground biomass dynamics in the Carbon Budget Model of the Canadian Forest Sector: recent improvements and implications for the estimation of NPP and NEP. Canadian Journal of Forest Research 33 (1): 126-136. - doi: 10.1139/ x02-165

MAF-ISAFA (1988). Inventario Forestale Nazionale (1985). Sintesi metodologica e risultati [National Forest Inventory 1985. Synthesis of methods and results]. Ministero Agricoltura e Foreste (MAF), Istituto Sperimentale Assestamento Forestale e Alpicoltura - ISAFA, Trento, Itay, pp. 461. [in Italian]

Marchetti M, Bertani R, Corona P, Valentini R (2012). Changes of forest coverage and land uses as assessed by the inventory of land uses in Italy. Forest@ 9 (4): 170-184. [in Italian with English abstract] - doi: 10.3832/efor0696-009

Masera OR, Garza-Caligaris JF, Kanninen M, Karjalainen T, Liski J, Nabuurs GJ, Pussinen A, De Jong BHJ, Mohren GMJ (2003). Modelling carbon sequestration in afforestation, agroforestry and forest management projects: the $\mathrm{CO} 2-$ FIX V. 2 approach. Ecological Modelling 164 (2-3): 177-199. - doi: 10.1016/S0304-3800(02) 00419-2

Mund M, Kummetz E, Hein M, Bauer GA, Schulze E-D (2002). Growth and carbon stocks of a spruce forest chronosequence in central Europe. Forest Ecology and Management 171 (3): 275-296. - doi: 10.1016/S0378-1127(01)007885

Oldeman RAA (1990). Forests: elements of silvology. Springer-Verlag, Heidelberg, Germany, pp. 624. - doi: 10.1007/978-3-642-75211-7 
Pasquettaz E (2014). La filiera bosco-energia [The wood-energy chain]. Rivista Environment, Ambiente e Territorio in valle d'Aosta, Assessorato territorio, ambiente e opere pubbliche, Regione Autonoma della Val d'Aosta, Italy. [in Italian] [online] URL: http://www.regione.vda.it/gestio ne/riviweb/templates/aspx/environnement.aspx? pkArt $=526$

Pilli R (2012). Calibrating CORINE Land Cover 2000 on forest inventories and climatic data: an example for Italy. International Journal of Applied Earth Observation and Geoinformation 19: 59-71. - doi: 10.1016/j.jag.2012.04.016

Pilli R, Grassi G, Kurz WA, Smyth CE, Blujdea V (2013). Application of the CBM-CFS3 model to estimate Italy's forest carbon budget, 1995-2020. Ecological Modelling 266: 144-171. - doi: 10.10 16/j.ecolmodel.2013.07.007

Puntelli L (2009). Le risorse forestali della Toscana [Forest resources of Tuscany]. Agraria.org, vol. 75. [in Italian] [online] URL: http://www. rivistadiagraria.org/riviste/vedi.php?news_id $=25$ 6\&cat_id $=85$

Regione Emilia Romagna (2008). Inventario Forestale Regionale. Risultati finali [Regional Forest Inventory. Final results]. Servizio Parchi e Risorse Forestali, Regione Emilia Romagna, Bologna, Italy, pp. 50. [in Italian]

Regione Marche (2008). Inventario e tipo forestale delle Marche [Forest inventory and forest types of Marche region]. Web site, Assessorato Agricoltura, Regione Marche, Ancona, Italy. [in Italian] [online] URL: http://www.agri.marche.it/ Areetematiche/foreste/inventarioetipiforestalidel leMarche/default.htm

Regione Sicilia (2014). Sistema Informativo Forestale [Forest Information System]. Web site, Comando del Corpo Forestale, Assessorato Regionale del Territorio e dell'Ambiente, Regione Siciliana, Palermo, Italy. [in Italian] [online] URL: http://sif.regione.sicilia.it/portale/itemde-
tail.do?body.sItemId $=481675 \&$ nav.sFolderId $=48$ $1675 \&$ sConceptTag $=$

Regione Umbria (2014). Foreste. Relazione sullo stato dell'Ambiente in Umbria [Forests. Report on the state of environment in Umbria]. ARPA, Perugia, Italy, vol. 8, pp. 290-303. [in Italian] [online] URL: http://www.arpa.umbria.it/au/rsa/ rsa/cap-08-5.pdf

Salvadori I, Pilli R, Anfodillo T (2006). A methodology for analysing temporal changes of forest surface using aerial photos for the application of Kyoto protocol: a study case in Northern Italy. Forest@ 3 (3): 339-350. [in Italian with English abstract] - doi: 10.3832/efor0393-0030 339

Stinson G, Kurz WA, Smyth CE, Neilson ET, Dymond CC, Metsaranta JM, Boisvenue C, Rampley GJ, Li Q, White TM, Blain D (2011). An inventory-based analysis of Canada's managed forest carbon dynamics, 1990 to 2008. Global Change Biology 17 (6): 2227-2244. - doi: 10.11 11/j.1365-2486.2010.02369.x

Tabacchi G, De Natale F, Floris A, Gagliano C, Gasparini P, Scrinzi G, Tosi V (2005). Italian national forest inventory: methods, state of the project, and future developments. In: Proceedings of the " $7^{\text {th }}$ Annual Forest Inventory and Analysis Symposium". Portland (ME, USA) 2005. USDA Forest Service, Washington, DC, USA, pp. 55-66.

Teobaldelli M, Federici S, Seufert G, Pagliari V, Blujdea V (2007). European forest yield tables database. AFOLU Project, Institute for Environment and Sustainability, Joint Research Centre, European Commission, Ispra, VA, Italy.

Thuille A, Buchmann N, Schulze ED (2000). Carbon stocks and soil respiration rates during deforestation, grassland use and subsequent Norway spruce afforestation in the Southern Alps, Italy. Tree Physiology 20 (13): 849-857. - doi: $10.1093 /$ treephys/20.13.849
Tonolli S, Salvagni F (2007). Inventario forestale del carbonio della provincia di Trento [Forest Carbon Inventory of Trento Province (NE, Italy)]. Ministero dell'Ambiente e della Tutela del territorio, Centro di Ecologia Alpina, Trento, Italy, pp. 173. [in Italian]

Tosi V, Marchetti M (1998). I sistemi informativi forestali in Italia: uniformità e divergenze tra gli inventari delle risorse forestali [Forest information systems in Italy: uniformity and differences between the inventories of forest resources]. L'Italia Forestale e Montana 5: 220-252. [in Italian]

Tosi V, Monteccone M (2004). Standards for large-scale forest inventories. A comparative study for Italy. Forest@ 1 (2): 148-164. [in Italian with English abstract] - doi: 10.3832/efor0235-00101 48

UNFCCC (2005). Decision 16/CMP. 1 - Land use, land-use change and forestry. United $\mathrm{Na}$ tions Convention on Climate Change. [online] URL: http://unfecc.int/resource/docs/2005/cmp 1/eng/08a03.pdf

UNFCCC (2011). Decision 2/CMP. 7 Land use, land-use change and forestry. United Nations Convention on Climate Change. [online] URL: http://unfccc.int/methods/lulucf/items/4152.php UNFCCC (2013). KP LULUCF tables, submission 2013. Web site, United Nations Fremawork Convention on Climate Change, Bonn, Germany. [online] URL: http://unfccc.int/national reports/ annex_i_ghg_inventories/national_inventories_s ubmissions/items/7383.php

UNFCCC (2014). KP LULUCF tables, submission 2014. Web site, United Nations Fremawork Convention on Climate Change, Bonn, Germany. [online] URL: http://unfecc.int/national_reports/ annex_i_ghg_inventories/national_inventories_s ubmissions/items/7383.php 